GRASAS Y ACEITES 71 (2)

April-June 2020, e351

ISSN-L: 0017-3495

https://doi.org/10.3989/gya.1284182

\title{
Optimization of the enzymatic pre-treatment process for mustard oilseeds using response surface methodology
}

\author{
T.S.V.R. Neeharika ${ }^{\mathrm{a}}$, K.N. Prasanna Rani ${ }^{\mathrm{b}}$, A. Thirupathi ${ }^{\mathrm{b}}$, E. Anjaneyulu ${ }^{\mathrm{b}}$, K. Srikanth ${ }^{\mathrm{b}}$, \\ B.L.A. Prabhavathi Devi ${ }^{\mathrm{b}}$, R.B.N. Prasad ${ }^{\mathrm{b}}$ and R.C.R. Jala ${ }^{\mathrm{b}, \mathrm{x}}$ \\ ${ }^{a}$ Chemical Engineering Division, \\ ${ }^{\mathrm{b}}$ Centre for Lipid Science \& Technology, \\ CSIR-Indian Institute of Chemical Technology, Hyderabad-500007, India \\ ${ }^{\square}$ Corresponding author: jrcreddy10@gmail.com; ramchandra@csiriict.in
}

Submitted: 28 December 2018; Accepted: 08 April 2019; Published online: 19 May 2020

SUMMARY: In order to investigate the effect of an enzymatic pre-treatment process for the extraction of oil from black mustard seeds (Brassica nigra) using viscozyme, the reaction parameters such as temperature, bufferto-seed ratio and enzyme concentration were considered as determinant factors in the central composite design. Optimization was carried out according to the four-variable five-level central composite design of experiments. The effects of enzyme concentration $(5-12 \%)$, temperature $\left(40-55^{\circ} \mathrm{C}\right), \mathrm{pH}(5.0-6.0)$, and reaction time $(1-7 \mathrm{~h})$ on the free oil liberated were studied. Residual oil was collected by subjecting the treated meal to soxhlet extraction for $4 \mathrm{~h}$. An enzyme dose of $7.5 \%(\mathrm{w} / \mathrm{w}), \mathrm{pH} 5.0,50^{\circ} \mathrm{C}$, and $5 \mathrm{~h}$ with constant shaking at $450 \mathrm{rpm}$ were found to be optimal conditions. Centrifuging the mixture at $7000 \mathrm{rpm}$ for $30 \mathrm{~min}$ separated the oil with a recovery of $71-73.1 \%$.

KEYWORDS: Enzymatic pre-treatment; Enzymes; Factorial design; Mustard seeds; Viscozyme

RESUMEN: Optimización de un pretratamiento enzimático para semillas de mostaza utilizando metodología de superficie de respuesta. Con el fin de investigar el efecto de un pretratamiento enzimático para la extracción de aceite de semillas de mostaza negra (Brassica nigra) utilizando viscozima, los parámetros de la reacción, como la temperatura, la relación de tampón/semilla y las concentraciones de enzima, se consideraron factores determinantes en el diseño. La optimización se llevó a cabo mediante cuatro diseños de experimentos compuestos de cinco niveles. Se estudió el efecto de la concentración de enzima $(5-12 \%)$, temperatura $\left(40-55^{\circ} \mathrm{C}\right)$, $\mathrm{pH}(5.0-6.0)$, y tiempo de reacción $(1-7 \mathrm{~h})$ sobre el aceite liberado. El aceite residual se recolectó sometiendo la pasta tratada a una extracción de soxhlet durante $4 \mathrm{~h}$. Las dosis de enzima del 7,5\% (p/p), pH 5,0,50 ${ }^{\circ} \mathrm{C}$ y $5 \mathrm{~h}$ con agitación constante a $450 \mathrm{rpm}$ fueron las condiciones óptimas. La centrifugación de la mezcla a 7000 rpm durante 30 minutos separó el aceite con una recuperación de 71-73.1\%.

PALABRAS CLAVE: Diseño factorial; Enzimas; Pretratamiento enzimático; Semillas de mostaza; Viscozima

ORCID ID: Neeharika TSVR https://orcid.org/0000-0002-1916-4692, Prasanna Rani KN https://orcid.org/0000-00029202-3845, Thirupathi A https://orcid.org/0000-0003-1403-5450, Anjaneyulu E https://orcid.org/0000-0002-3576-8824, Srikanth K https://orcid.org/0000-0003-4496-5106, Prabhavathi Devi BLA https://orcid.org/0000-0001-9785-7999, Prasad RBN https://orcid.org/0000-0002-7781-7751, Jala RCR https://orcid.org/0000-0001-7428-1712

Citation/Cómo citar este artículo: Neeharika TSVR, Prasanna Rani KN, Thirupathi A, Anjaneyulu E, Srikanth K, Prabhavathi Devi BLA, Prasad RBN, Jala RCR. 2020. Optimization of the enzymatic pre-treatment process for mustard oilseeds using response surface methodology. Grasas Aceites 71 (2), e351. https://doi.org/10.3989/gya.1284182

Copyright: (C2020 CSIC. This is an open-access article distributed under the terms of the Creative Commons Attribution 4.0 International (CC BY 4.0) License. 


\section{INTRODUCTION}

In response to a recently increasing trend the worldwide mustard production is expected to reach up to 70-72 million tonnes (Mt) in 2017-18. Due to the balanced mono and polyunsaturated fatty acid profile, it is suggested to incorporate mustard oil into domestic cooking (Swati et al., 2015). In India, mustard oil is usually extracted using mechanical expellers, and only a small proportion of oil is extracted through the solvent extraction process (Swati et al., 2015). Mechanical extraction is a conventional process of oil extraction and about 6-8\% of the oil remains in the oilseed cake using this process (Swati et al., 2015). Enzymes, namely cellulase, pectinase, $\beta$-glucanase, and protease, are produced by microorganisms and have tremendous potential in the food industry. Enzyme consortia, comprising of enzymes such as cellulase, pectinase, protease, helps in hydrolyzing the cell wall polysaccharides of oilseeds, thereby improving the recovery of oil from the seeds (Domínguez et al., 1994). The advantages of using an enzymatic pre-treatment prior to extraction are low energy consumption and solvent usage, good quality oil, and good quality of protein in the oil cake (Domínguez et al., 1994). Since a mixture of cellulase, pectinase, and protease is needed for the breakdown of bonds between lipoproteins and lipopoly saccharides present in mustard seeds, all these enzymes are needed for the pre-treatment of oilseeds.

Oil in oilseeds is generally bound to either proteins as lipoproteins or to the insoluble polysaccharides as lipopolysaccharides. Although in a multienzyme hydrolysis of the cell wall it is not possible to ascertain the role played by each component, it is felt that cellulase, pectinase, and protease were dominant in the hydrolysis of the cell wall of mustard seeds. The phospholipids and protein may form lipoproteic membranes that surround the oil drops during grinding (Domínguez et al., 1994). Thus, the presence of protease in the enzyme consortium might have aided in releasing oil from the lipoproteic membrane of the cell walls of mustard seeds. As discussed earlier, Trichoderma reesei alone and in combination with Aspergillus niger produced higher FPU gds ${ }^{-1}$, compared to A. niger alone, indicating an important role for cellulase in oil recovery. Cellulase was predominant in the hydrolysis of the strong intermolecular interactions present between the cellulose molecules. Pectic substances are the prevalent cell wall polysaccharides in rapeseed. Thus an enzyme combination results in effective degradation of cell walls, leading to the release of most of the oil enmeshed within the cells into the aqueous medium. Several oilseeds, namely sunflower (Danso et al., 2011), sesame (Sarkar et al., 2004), rapeseed (Koehler et al., 2008), rubber seed (Zu et al., 2013), evening primrose (Wang et al., 2014), Jatropha (Shah et al., 2004), jojoba (Shabtai et al., 1998), Moringa oleifera (Abdulkarim et al., 2006), Ricinodendron heudelotii (Bail.) and Pierre ex Pax (Dandjouma et al., 2008) were subjected to enzymatic pre-treatment for maximum oil extraction. However, not many enzymatic pre-treatment studies were conducted for the efficient extraction of oil from mustard oilseeds. The chemical composition of mustard seeds was found to be protein $24.0-36.0 \%$, fat $31.0-38.5 \%$, carbohydrates $16-21 \%$, water $4.4-5.1 \%$, fiber $5.9-6.4 \%$ and ash $4.0-4.3 \%$. Mustard seeds consist of several chemical constituents like phytoalexins (sinalbins $\mathrm{A}$ and $\mathrm{B}$, sinalexin), sterols and steryl esters (mainly sitosterol and campesterol) and flavonoids (chalcone, apigenin). Mustard oil faces color and odor problems. The pungency is produced by glucosinolates, which are hydrolyzed by the myrosinase enzyme (a thioglucoside glucohydrolase) to flavor active isothiocyanates in mustard oil (Fahad et al., 2012; Abdul et al., 2011).

Dobozi et al., (1988) reported a treatment for mustard seeds with a celluloytic enzyme, resulting in an increase in $20-30 \%$ oil yield for $2 \mathrm{~h}$ at $35^{\circ} \mathrm{C}$ and $\mathrm{pH} 4.85$ was found to be the most effective condition. Pawanpreet et al., (2013) applied response surface methodology for the optimization of operational parameters for the enhancement of oil recovery from mustard seeds using mechanical expression and Allzyme (Allzyme is a combination of protease, cellulose, pectinase, etc. which helped release the oil). A Central Composite Rotatable Design (CCRD) was used for optimatization and resulted in a maximum of 8 to $8.89 \%$ at optimum conditions. Hariender et al., (2012) used crude enzyme obtained from the solid state fermentation of kinnow waste and wheat bran with $A$. niger, $T$. reesei individually and in combination for recovering oil from mustard seeds. The pre-treatment produced an $11 \%$ increase compared to control experiments (Pre-treatment with mixed extract produced $34.32 \pm 0.98 \%$ recovery compared to conventional $31.52 \pm 0.87 \%$ oil). Sengupta et al., (1996) used a combination of cellulose and pectinase for the aq. enzymatic extraction of mustard seeds. At $4.5 \mathrm{pH} 50^{\circ} \mathrm{C}$ temperature for $4 \mathrm{~h}$ and $2 \%$ enzyme, at water:seed ratio of 2 and 5:1 hexane/seed ratio gave $100 \%$ recovery. Tabtabaei et al., (2013) reported the carbohydrase treatment of yellow mustard flour individually or in combination with cellulose, hemicellulase and pectinase for enzymatic pre-treatment. In this study, the enzymatic pre-treatment was conducted for $3 \mathrm{~h}$ using $3 \mathrm{wt} \%$ enzyme at $4.8-5.0 \mathrm{pH}$ and $40-42{ }^{\circ} \mathrm{C}$ temperatures.

The scope of the present study was to optimize the process variables of the enzymatic pre-treatment such as enzyme concentration, temperature, $\mathrm{pH}$, reaction time, temperature, buffer-to-seed ratio for the extraction of oil from mustard seeds using viscozyme. The black mustard seeds (Brassica 
nigra) were taken for the study and response surface methodology was used to assess the optimization process. Employing novel enzyme possessing multiple enzyme characteristics, increased oil recovery and simplified experimental protocol are the highlights of the present work compared to previous studies.

\section{MATERIALS AND METHODS}

\subsection{Materials}

The black mustard seeds (Brassica nigra) used in the experiments were purchased from the local market. Viscozyme L (cellulolytic enzyme mixture) was supplied by Novozymes (Denmark). All the chemicals, hexane, citric acid and sodium citrate were of analytical grade and were procured from M/s. Sd Fine Chem. Pvt. Ltd., Mumbai.

\subsection{Methods}

\subsubsection{Experimental setup}

The experimental set up consisted of a hotplate showing a digital display for temperature and rpm. The maximum stirring speed was $700 \mathrm{rpm}$. The temperature was set up to $180{ }^{\circ} \mathrm{C}$. The mustard seed powder was weighed and enzyme and a $\mathrm{pH}$ buffer solution were added to a round-bottom flask. A magnetic bead was placed inside the round-bottom flask to help with stirring. The temperature and rpm were set as required.

\subsubsection{Experimental procedure}

The experimental procedure was the modified method of the reported one (Domínguez et al., 1994). $5 \mathrm{~g}$ of well ground black mustard seed powder were placed in a round-bottom flask $(250 \mathrm{ml})$ and $10 \mathrm{~g}$ of distilled water were added (in 1:2 ratio) and the contents were stirred at $90{ }^{\circ} \mathrm{C}$ for $15 \mathrm{~min}$ to deactivate the native myrosinase enzyme present in black mustard seeds. The mixture was then cooled to room temperature and 7\% viscozyme (7 $\mathrm{wt}^{\mathrm{O}} \%$ based on oil weight) dissolved in $25 \mathrm{ml}$ of $\mathrm{pH} 5.0$ citrate buffer (in 1:5 ratio) was added. The reaction mixture was maintained at $50{ }^{\circ} \mathrm{C}$ and continuously stirred at $600 \mathrm{rpm}$ for $5 \mathrm{~h}$. After enzymatic reaction, the mixture was subjected to the de-activation of viscozyme at $80^{\circ} \mathrm{C}$ for $5 \mathrm{~min}$. The mixture was then cooled, $7.5 \mathrm{ml}$ hexane were added $(1: 1.5(\mathrm{w} / \mathrm{v}))$ and it was stirred at room temperature for $15 \mathrm{~min}$. The contents were centrifuged at $7000 \mathrm{rpm}$ for $30 \mathrm{~min}$. The contents were filtered and the hexane phase was desolventized and dried under high vacuum. The solid phase (containing treated powder) was dried at $100{ }^{\circ} \mathrm{C}$ to remove moisture. The dried powder was subjected to soxhlet extraction using hexane for $4 \mathrm{~h}$ and the extract was subjected to rota-evaporation to remove the solvent. This was further dried under high vacuum to remove moisture and the weight of oil was noted. The same procedure was repeated again with the residual cake to collect the residual amount of oil present in the cake. The percentage total extractable oil was calculated as the percentage of the oil content in the liquid phase on the total oil present in the mustard seed powder. A triplicate determination was performed.

\subsubsection{Experimental design}

A four-variable five-level central composite design of experiments was used to determine the effect of process conditions on the enzymatic pretreatment of mustard seeds such as enzyme dosage, temperature, time and $\mathrm{pH}$ on oil yield. All the experimental runs were carried out at random, in triplicate, for error estimation. Coded and uncoded values for the variables and their levels, and experimental design matrix a are given in Tables 1 and 2, respectively.

\subsubsection{Scanning electron microscopic (SEM)}

To know the consequences of the enzymatic pretreatment for oil mustard seeds, the seed kernels were subjected to scanning electron microscopy of the enzyme treated and untreated mustard seeds. The kernel samples were cut with a razor blade. The physical properties of these samples were characterized by Scanning Electron Microscopy, SEM (JEOL JSM-7610F Field Emission Scanning Electron Microscope) employed by the CSIR-Indian Institute of Chemical Technology. A microscope operated at $2,5,15 \mathrm{kV}$ at working distances of 6 , $8,15 \mathrm{~nm}$. Cut seed samples were placed carefully on the clean disk with double- sided tape for the SEM imaging of about $10 \mathrm{~min}$ with a resolution of 5,000 for the selected samples.

\subsubsection{Statistical analyses}

All the experimental results shown in this study are arithmetic means of triplicate determinations with a confidence interval of $95 \%$.

TABLE 1. Coded and uncoded values of variables and their levels

\begin{tabular}{lcrrrrr}
\hline Independent variable & Coded levels & $\mathbf{- 2}$ & $\mathbf{- 1}$ & $\mathbf{0}$ & $\mathbf{1}$ & $\mathbf{2}$ \\
\hline Enzyme dosage (\%) & $\mathrm{A}$ & 1 & 3 & 5 & 7 & 9 \\
Temperature (C) & $\mathrm{B}$ & 35 & 40 & 45 & 50 & 55 \\
Time (h) & $\mathrm{C}$ & 2 & 3 & 4 & 5 & 6 \\
$\mathrm{pH}$ & $\mathrm{D}$ & 3.5 & 4 & 4.5 & 5 & 5.5 \\
\hline
\end{tabular}


TABLE 2. Experimental design matrix

\begin{tabular}{|c|c|c|c|c|c|c|c|}
\hline Std Order & Run order & Type & Enzyme (\%) & Temperature (C) & Time (h) & $\mathrm{pH}$ & Yield \\
\hline 1 & 18 & Factorial & 3.00 & 40.00 & 3.00 & 4.00 & 33.25 \\
\hline 2 & 1 & Factorial & 7.00 & 40.00 & 3.00 & 4.00 & 33.5 \\
\hline 3 & 8 & Factorial & 3.00 & 50.00 & 3.00 & 4.00 & 33.6 \\
\hline 4 & 4 & Factorial & 7.00 & 50.00 & 3.00 & 4.00 & 34.18 \\
\hline 5 & 3 & Factorial & 3.00 & 40.00 & 5.00 & 4.00 & 33.45 \\
\hline 6 & 30 & Factorial & 7.00 & 40.00 & 5.00 & 4.00 & 33.86 \\
\hline 7 & 6 & Factorial & 3.00 & 50.00 & 5.00 & 4.00 & 34.05 \\
\hline 8 & 25 & Factorial & 7.00 & 50.00 & 5.00 & 4.00 & 35.17 \\
\hline 9 & 21 & Factorial & 3.00 & 40.00 & 3.00 & 5.00 & 33.25 \\
\hline 10 & 7 & Factorial & 7.00 & 40.00 & 3.00 & 5.00 & 33.93 \\
\hline 11 & 20 & Factorial & 3.00 & 50.00 & 3.00 & 5.00 & 33.8 \\
\hline 12 & 15 & Factorial & 7.00 & 50.00 & 3.00 & 5.00 & 35.15 \\
\hline 13 & 17 & Factorial & 3.00 & 40.00 & 5.00 & 5.00 & 33.62 \\
\hline 14 & 28 & Factorial & 7.00 & 40.00 & 5.00 & 5.00 & 34.8 \\
\hline 15 & 14 & Factorial & 3.00 & 50.00 & 5.00 & 5.00 & 34.6 \\
\hline 16 & 27 & Factorial & 7.00 & 50.00 & 5.00 & 5.00 & 36.7 \\
\hline 17 & 11 & Axial & 1.00 & 45.00 & 4.00 & 4.50 & 33.36 \\
\hline 18 & 24 & Axial & 9.00 & 45.00 & 4.00 & 4.50 & 35.3 \\
\hline 19 & 10 & Axial & 5.00 & 35.00 & 4.00 & 4.50 & 33.03 \\
\hline 20 & 26 & Axial & 5.00 & 55.00 & 4.00 & 4.50 & 34.75 \\
\hline 21 & 16 & Axial & 5.00 & 45.00 & 2.00 & 4.50 & 33.67 \\
\hline 22 & 2 & Axial & 5.00 & 45.00 & 6.00 & 4.50 & 34.98 \\
\hline 23 & 5 & Axial & 5.00 & 45.00 & 4.00 & 3.50 & 33.68 \\
\hline 24 & 23 & Axial & 5.00 & 45.00 & 4.00 & 5.50 & 34.65 \\
\hline 25 & 9 & Center & 5.00 & 45.00 & 4.00 & 4.50 & 34.65 \\
\hline 26 & 29 & Center & 5.00 & 45.00 & 4.00 & 4.50 & 34.61 \\
\hline 27 & 22 & Center & 5.00 & 45.00 & 4.00 & 4.50 & 34.78 \\
\hline 28 & 12 & Center & 5.00 & 45.00 & 4.00 & 4.50 & 34.72 \\
\hline 29 & 13 & Center & 5.00 & 45.00 & 4.00 & 4.50 & 34.65 \\
\hline 30 & 19 & Center & 5.00 & 45.00 & 4.00 & 4.50 & 34.6 \\
\hline
\end{tabular}

\section{RESULTS AND DISCUSSION}

\subsection{Effect of reaction time}

The rate of hydrolysis of a reaction depends on reaction time. The reaction parameters were optimized at $7 \%$ catalyst concentration, $50{ }^{\circ} \mathrm{C}$ temperature, $1: 5$ buffer ratio at $\mathrm{pH} 5$. Figure 1 shows a linear plot as a function of reaction time and extracted oil. Initially, it was found that after $1 \mathrm{~h}$ of reaction, extraction was $33.94 \%$ and after $3 \mathrm{~h}$ of reaction, $36.29 \%$ oil was obtained and extraction increased with respect to time and reached a maximum value of $38.76 \%$ within $5 \mathrm{~h}$. This may be due to the equilibrium being achieved over that time period. Gradually increasing the reaction time increased oil recovery to an optimum level. This means viscozyme $\mathrm{L}$, being a cellulolytic enzyme mixture, degraded the cellulose-based mustard seed cell walls efficiently during this reaction period. However, a further increase in the reaction time to $7 \mathrm{~h}$ yielded an extraction of about $39.02 \%$, indicating that it did not produce any significant changes in the conversion rate. Subsequently, the reaction was optimized at $5 \mathrm{~h}$ reaction time as a shorter incubation time will be more advantageous because energy expenditure and time play crucial roles in industrial extraction processes. Figure 1 shows the trend of extraction with time.

\subsection{Effect of enzyme dosage}

The effect of amount of enzyme on the pretreatment of mustard seeds was studied in the range of 5 to $12 \%$ using viscozyme with a $1: 5$ buffer ratio at $\mathrm{pH} 5$ and $50{ }^{\circ} \mathrm{C}$ temperature for $5 \mathrm{~h}$ (Figure 2). 


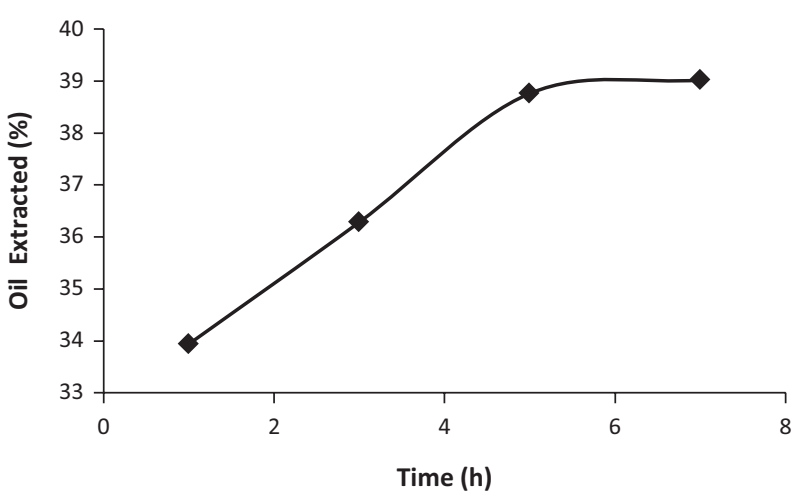

FigurE 1. Effect of reaction time.

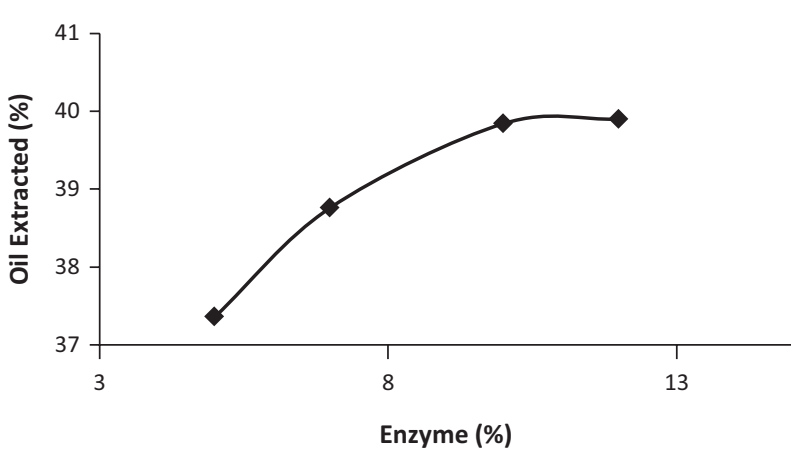

FIGURE 2. Effect of enzyme dosage.

There was a considerable increase in oil extraction when enzyme dosage increased from 5 to $7 \%$. It is obvious that when enzyme concentration was increased, more enzyme catalytic surfaces were available for reaction. This will enhanced the number of collisions, thus increased the rate of reaction. When the enzyme dosage was 5\% the extraction was $37.36 \%$, further increasing to $7 \%$ resulted in an increase of up to $38.76 \%$ oil extraction. A rise in enzyme dosage to $10 \%$ resulted in a slight increase in oil extraction (reached $39.84 \%$ ). Since there was not much difference found between 7 and 10\% enzyme dosage extractions, the latter was not recognized as optimum. Further increasing the enzyme dosage to $12 \%$ yielded an oil extraction of $39.90 \%$. Considering the above facts, $7 \%$ enzyme dosage was taken for further reactions.

Higher amounts of enzyme and longer reaction times generally correlate with an increase in the extraction yield. However, the high cost of enzymes associated with increasing enzyme dosage would affect the economy of the process.

\subsection{Effect of reaction temperature}

The effect of temperature was evaluated at $40{ }^{\circ} \mathrm{C}$ to $55^{\circ} \mathrm{C}$ where the other reaction parameters were kept constant i.e., enzyme concentration at $7 \%$,

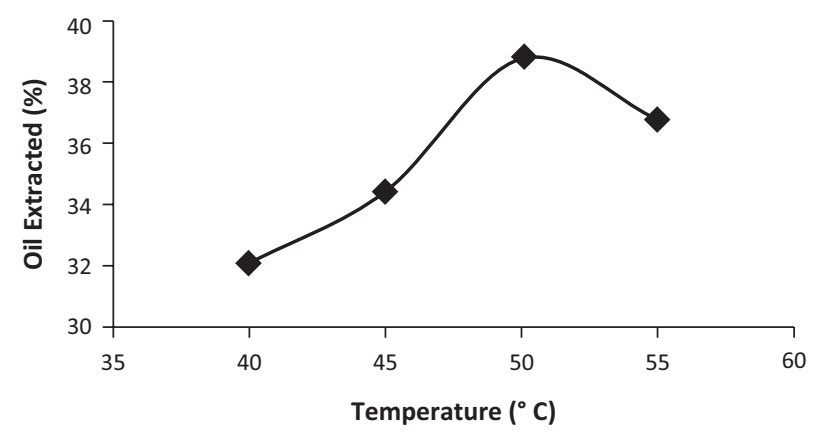

FIGURE 3. Effect of reaction temperature.

using 1:5 buffer ratio for $5 \mathrm{~h}$ of reaction time. At $40{ }^{\circ} \mathrm{C}$ the oil extraction was $32.09 \%$ and when it was increased to $45^{\circ} \mathrm{C}$, oil extraction increased to $34.42 \%$, and further increasing to $50{ }^{\circ} \mathrm{C}$ it was $38.76 \%$. Increasing temperature from $40-50{ }^{\circ} \mathrm{C}$ increased the oil extraction by up to $38.76 \%$, whereas further increasing to $55^{\circ} \mathrm{C}$ decreased the oil extraction to $36.77 \%$. This is because increasing the temperature to certain level allows the molecules to move quickly with greater energy, causing more collisions and therefore increasing the rate of reaction. The temperature profile of the enzymatic reaction is shown in Figure 3.

\subsection{Effect of seed-to-buffer ratio}

The effect of citrate buffer concentration on the extraction of oil was investigated with ratios 1:4 to $1: 6$. The rate of reaction is increased by increasing the amount of buffer solution. The data showed that for a ratio of $1: 4$, the oil extraction was $37.96 \%$, and by increasing the buffer to $1: 4.5$ and $1: 5$ the extraction percentage was increased to $38.09 \%$ and $38.76 \%$, respectively. Further increasing to $1: 5.5$ gave $37.97 \%$ oil extraction. However, no prominent change was observed after increasing to a 1:6 ratio. As the buffer quantity increased the interfacial area, the conversion was thereby increased and the optimal ratio of buffer was found to be 1:5 and this trend is illustrated in Figure. 4. Hence, the generation of high interfacial area plays a significant role in improving the rate of the reaction.

\subsection{Effect of pH of citrate buffer}

Changing the $\mathrm{pH}$ favors the enzymes that are most active at that particular $\mathrm{pH}$. The effect of the $\mathrm{pH}$ of the buffer on the extraction of oil was investigated from 2 to $6 \mathrm{ml}$. Figure 5 shows the effect of extractability as a function of buffer $\mathrm{pH}$. It was observed that for $\mathrm{pH} 4.5$, the extraction was $36.13 \%$; by increasing the $\mathrm{pH}$ of the buffer to 5.0 the extraction percentage increased to 38.76 . Further increasing to 5.5 gave $36.56 \%$ oil extraction; however, increasing the 


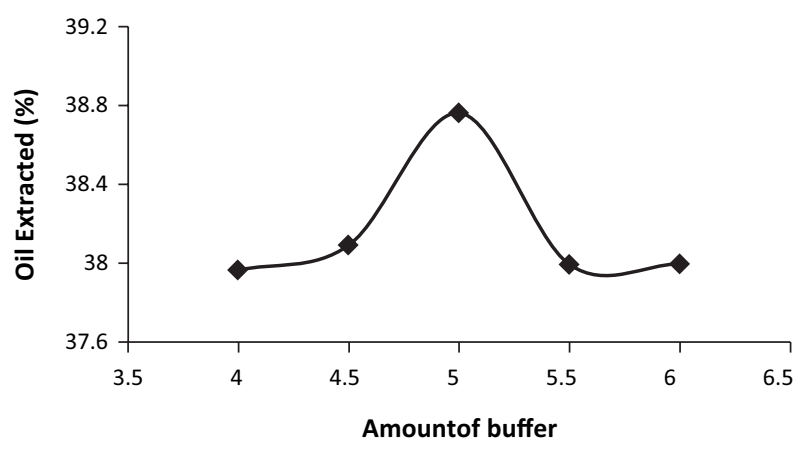

FIGURE 4. Effect of seed-to-buffer ratio.

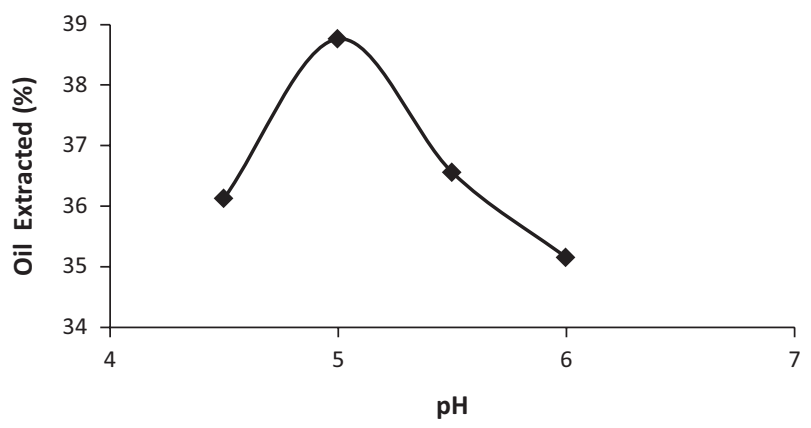

Figure 5. Effect of citrate buffer $\mathrm{pH}$ on extraction.
$\mathrm{pH}$ to 6.0 resulted in $35.15 \%$ oil extraction and the optimal $\mathrm{pH}$ of the buffer was found to be 5 . The oil was best recovered at $\mathrm{pH} 5$, which indicates that the enzymes are most likely to function best at this $\mathrm{pH}$.

The oil recovery data were analyzed by employing the multiple regression technique. It reveals that the model predicting enhanced oil yield is significant at $99 \%$ level of significance. $\mathrm{P}$ values less than 0.05 reveals that the model terms are significant.

The model was prepared by fitting the response to the factors. The ANOVA of the response surface quadratic model is provided in Table 3 . As the $p$-value for the model was lower than 0.05 there was a statistical relation among the response and the selected variables at $95 \%$ confidence level. Second-order models were gained to predict the responses analyzed as a function of the variables. The following expression was attained and it can be seen from the data analysis by ANOVA. The ANOVA results imply that the model is significant i.e., A, B, C, D, AB, AC, AD, BC, BD, CD, A2, B2, C2, D2 are significant. The predictive best fit regression equation for enhanced oil yield is:

$$
\begin{aligned}
\text { Yield }= & +23.49299-1.36286^{*} A+0.461573^{*} B \\
& -1.29552^{*} C+1.42396^{*} D+0.016438^{*} A^{*} B \\
& +0.060938^{*} A^{*} C+0.18438^{*} A^{*} D \\
& +0.024875^{*} B^{*} C+0.042750^{*} B^{*} D \\
& +0.19875^{*} C^{*} D-0.020964^{*} A^{2}-7.75417 E \\
& -003^{*} B^{2}-0.085104^{*} C^{2}-0.50042^{*} D^{2}
\end{aligned}
$$

\begin{tabular}{|c|c|c|c|c|c|c|}
\hline Source & Sum of Squares & df & Mean Square & F Value & $p$-value & \\
\hline Model & 18.52 & 14 & 1.32 & 163.43 & $<0.0001$ & significant \\
\hline A-EnzymeComcnetration & 5.56 & 1 & 5.56 & 686.56 & $<0.0001$ & \\
\hline B-temperature & 5.07 & 1 & 5.07 & 626.13 & $<0.0001$ & \\
\hline C-Time & 2.81 & 1 & 2.81 & 346.90 & & \\
\hline$D-p H$ & 1.89 & 1 & 1.89 & 233.10 & $<0.0001$ & \\
\hline$A B$ & 0.43 & 1 & 0.43 & 53.40 & $<0.0001$ & \\
\hline$A C$ & 0.24 & 1 & 0.24 & 29.35 & $<0.0001$ & \\
\hline$A D$ & 0.54 & 1 & 0.54 & 67.18 & $<0.0001$ & \\
\hline$B C$ & 0.25 & 1 & 0.25 & 30.57 & $<0.0001$ & \\
\hline$B D$ & 0.18 & 1 & 0.18 & 22.57 & 0.0003 & \\
\hline$C D$ & 0.16 & 1 & 0.16 & 19.52 & 0.0005 & \\
\hline$A 2$ & 0.19 & 1 & 0.19 & 23.82 & 0.0002 & \\
\hline$B 2$ & 1.03 & 1 & 1.03 & 127.31 & $<0.0001$ & \\
\hline$C 2$ & 0.20 & 1 & 0.20 & 24.54 & 0.0002 & \\
\hline D2 & 0.43 & 1 & 0.43 & 53.02 & $<0.0001$ & \\
\hline Residual & 0.12 & 15 & $8.096 \mathrm{E}-003$ & & & \\
\hline Lack of Fit & 0.098 & 10 & $9.756 E-003$ & 2.04 & 0.2228 & not significant \\
\hline Pure Error & 0.024 & 5 & $4.777 E-003$ & & & \\
\hline Cor Total & 18.65 & 29 & & & & \\
\hline
\end{tabular}

Table 3. ANOVA for Response Surface Quadratic Model 
Where,
A is Enzyme concentration
$\mathrm{B}$ is Temperature
$\mathrm{C}$ is Time
$\mathrm{D}$ is $\mathrm{pH}$

The regression equation and the determination coefficient $\left(\mathrm{R}^{2}\right)$ were evaluated to test the fit of the model. In this case, the value of the determination coefficient was 0.9935 . The predicted $\mathrm{R}^{2}$ square value (0.9680) is in good agreement with the adjusted $\mathrm{R}^{2}$ square value $(0.9874)$.

Figure 6 shows the residual distribution over the observed values for the response studied. A good fit was observed because the residual distribution does not follow a trend with regard to the predicted variables. The comparison of the experimental and calculated responses for the model shows the agreement between the observed and predicted values. The Figure 7 shows that the mathematical model used for the prediction of the response provides good agreement for the experimental data. Figure 8 shows the normal probability plot of the residuals indicating a good validity for the linear regression model.

The random distribution of the residuals (Figure 6) shows the absence of a trend which also indicates that the mathematical model is adequate since it does not detect any inconsistency between experimental and calculated values. It must be emphasized that the model equation is an empirical equation that describes the relation between the oil yield and the reaction conditions in our experiments.
The response surface plots were generated for different interactions of two variables while keeping the other parameters constant. The significance of linear and interaction co-efficient were studied at the $p$ value of less than 0.0001 . The predicted and actual white mustard seed oil yields under the optimal conditions $\left(70^{\circ} \mathrm{C}, 6.5: 1 \mathrm{ml}\right.$ of solvent per $\mathrm{g}$ of seed cake and $5 \mathrm{~min}$ ) were 7.3 and $7.2 \mathrm{~g} / 100 \mathrm{~g}$, respectively. By employing the two-step process, the white mustard seed oil yield of $20.5 \mathrm{~g} / 100 \mathrm{~g}$ was achieved, which was $99.2 \%$ of the white mustard seed oil yield obtained by the soxhlet extraction. According to Stamenković et al., (2018) the two-step process could replace the energy and solvent-intensive soxhlet extraction of white mustard seed oil. According to Singh and Singh, (2013) the optimum conditions for maximum oil recovery are $9 \%$ moisture content, $4 \%$ enzyme dosage, $60{ }^{\circ} \mathrm{C}$ reaction temperature and $8 \mathrm{~min}$ reaction time for the PBR-91 variety, whose predicted value for oil recovery is $29.82 \%$, acid value of 0.8315 and peroxide value of 5.42; whereas for the RLC-1 variety the optimal conditions are $9 \%$ moisture content, $4 \%$ enzyme dosage, $60{ }^{\circ} \mathrm{C}$ reaction temperature and 4 min reaction period, whose predicted value for oil recovery is $29.0 \%$, acid value is 0.69 and peroxide value is 4.70 . However, in the present study, at the optimal conditions the enzyme dosage of $7.5 \%(\mathrm{w} / \mathrm{w}), \mathrm{pH} 5.0,50{ }^{\circ} \mathrm{C}$, and $5 \mathrm{~h}$ with constant shaking at $450 \mathrm{rpm}$, centrifuging the mixture at $7000 \mathrm{rpm}$ for $30 \mathrm{~min}$ separated the black mustard oil with a recovery of 71-73.1\%. Employing novel enzyme possessing multiple enzyme characteristics,

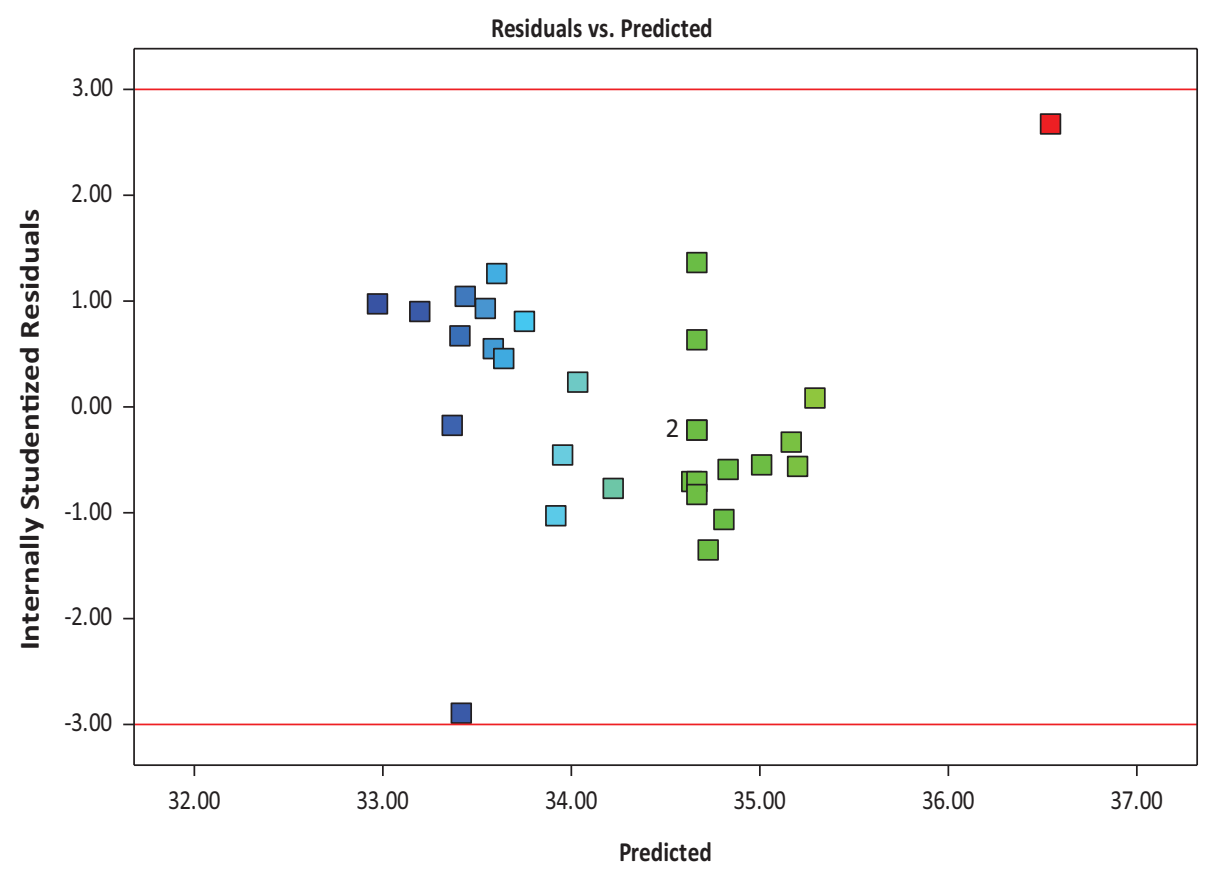

FIGURE 6. Residual plots of oil yield for the model. 


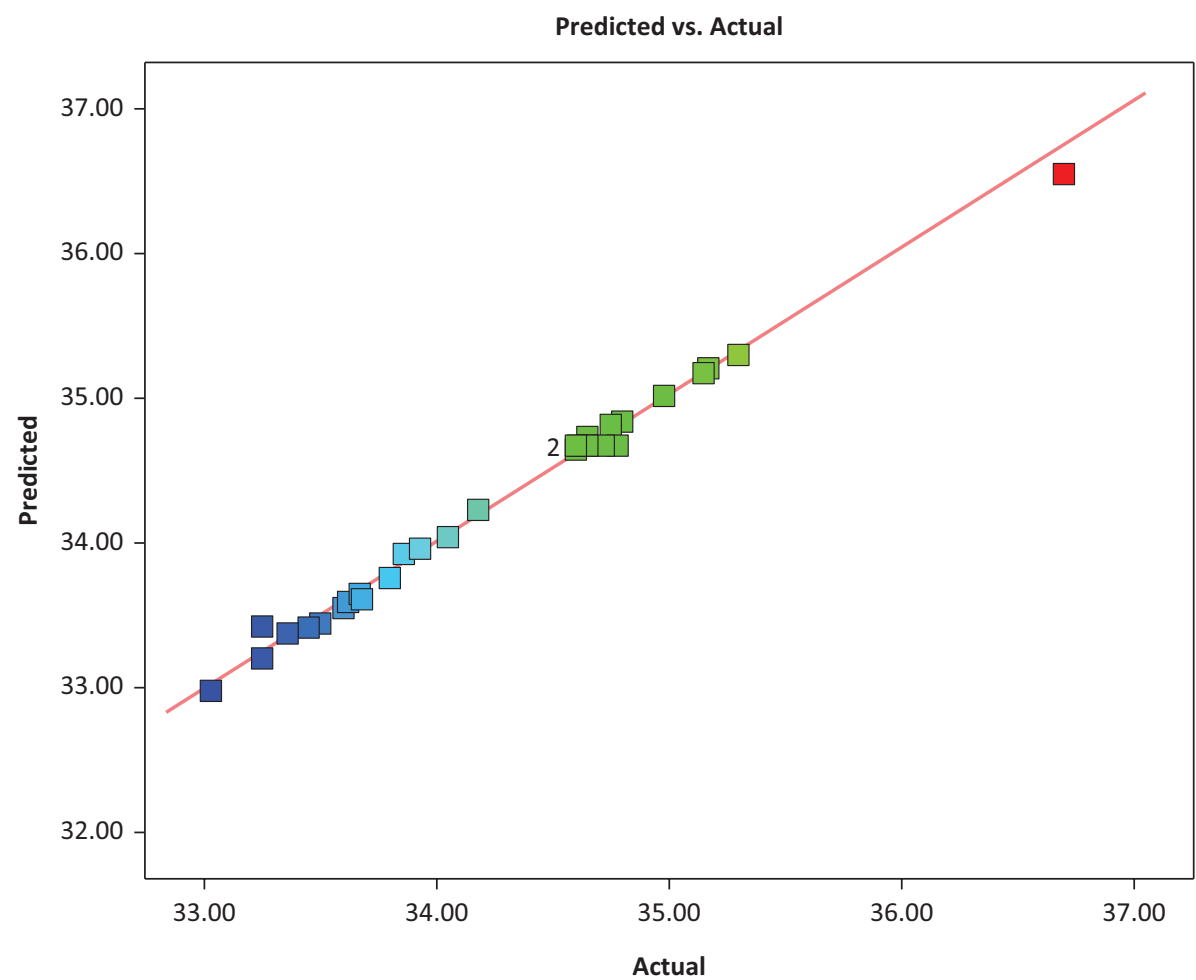

Figure 7. Predicted values vs. experimental values for the model.

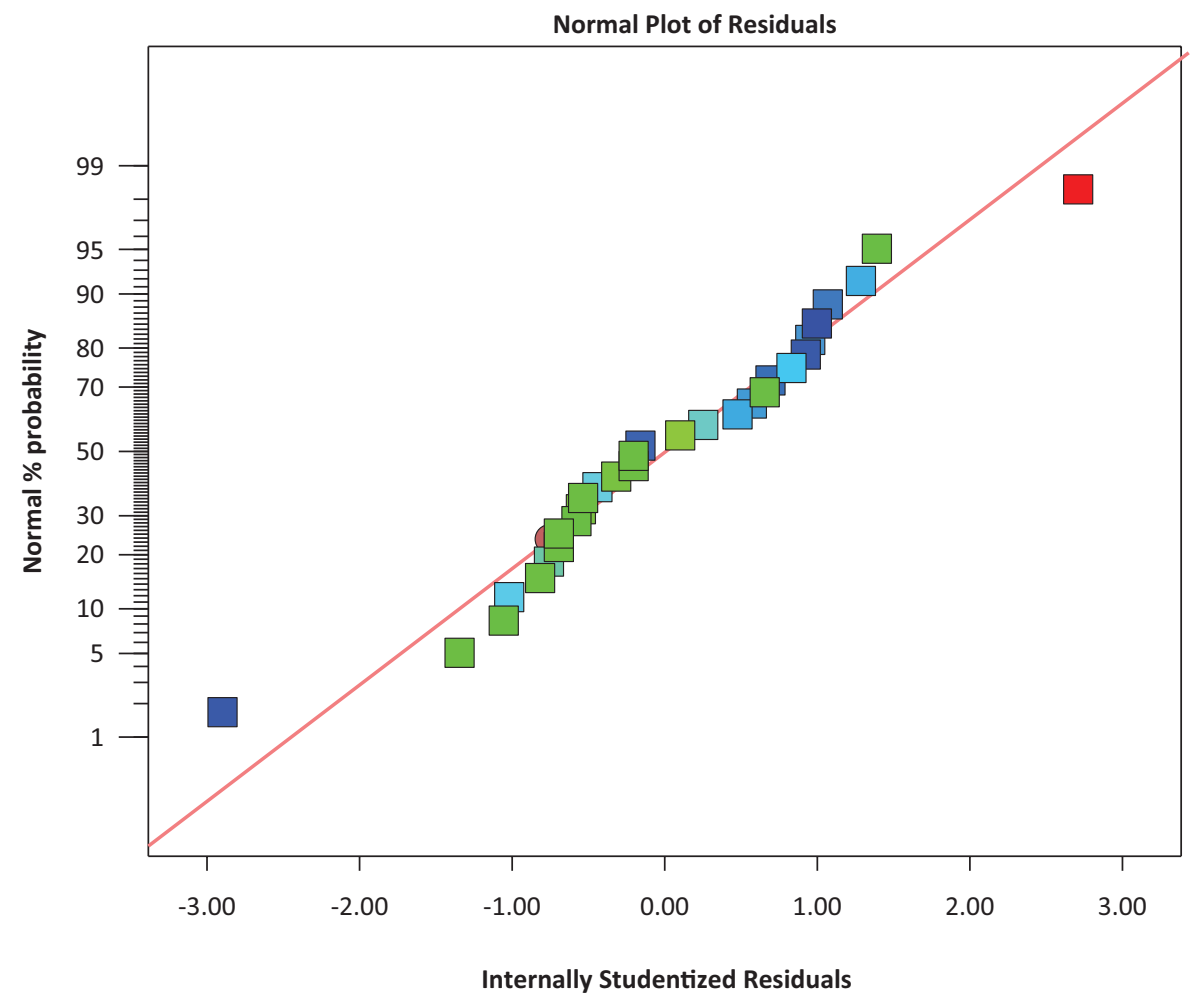

FIGURE 8. Normal probability plot of residuals. 
increased oil recovery, and simplified experimental protocols are the highlights of the present work compared to previous studies. Viscozyme is the multi-enzyme complex containing a wide range of carbohydrates, including arabinase, cellulase, $\beta$-glucanase, hemicellulase and xylanase enzymes. In the case of $\alpha$-amylase, no significant improvement in oil yield was observed. This may be due to absence of amylose in mustard meal. Viscozyme exhibited very good performance as enzymatically pre-treated mustard meal yielded up to $38.76 \%$ oil (5 h reaction time); whereas direct soxhlet extraction of meal yielded only $33.6 \%$. This could be attributed to a variety of enzymes in viscozyme which works on cellulose, hemicellulose, and other carbohydrates. Compared to the reported work (Pawanpreet et al., 2013, 29\% oil recovery; Harinder singh et al., 2012, 34.32\% oil recovery) in our study better oil recovery was achieved. Sengupta claimed good oil recovery (claiming $100 \%$ oil recovery), but used mixture of enzymes, whereas in our study we have used a single enzyme possessing multiple enzymatic characteristics. The presence of all enzyme characteristics in a single enzyme was significantly $(P<0.05)$ more effective than when used individually. The slight increase with a mixture of enzymes yielded more oil because of their combined effect on colloidal and lipoproteic structures (Dominguez et al., 1994). Indeed oils are locked within the matrix of the interacting macromolecules; the successful disruption of this close association by using an enzyme having multiple activities to digest the various components will result in the release of more oil contained within the matrix. This is in accordance with the work of several researchers who have reported an increase in oil recovery when combinations of enzymes were used. Further, in our study a simplified enzymatic pre-treatment process was developed.

It has been shown that enzymes, when used under optimal conditions, significantly enhanced the recovery of oil compared to traditional methods. In general, enzyme-extracted oils had lower acid values and color intensities (no bleaching is required). Also because the enzymatic-extraction process was carried out in an aqueous medium, the possibility of phospholipids and other water-soluble gums are separated from the oil so that there is no need for de-gumming, which reduces the overall cost of the refining process. It is safer to use enzymes rather than solvents, which are hazardous and difficult to dispose of after use.

\subsection{Scanning electron microscopy (SEM)}

The scanning electron microscopic images of the enzyme-treated and untreated mustard seeds clearly depict the consequences of enzymatic pre-treatment on oil mustard seeds. It is clearly evident from the figure that the application of enzymes for pre-treatment resulted in an increased extent of free oil release from the mustard seeds. As Viscozyme $L$ is a cellulolytic enzyme mixture it produces a breakdown of cellular structures to obtain a total degradation of cell walls resulting in the releasing of more oil (Domniguez et al., 1994; Olsen BS. 1986). According to Ravindra and John, (2013) the effect of enzymatic action on the degradation of cell wall for increasing the release of oil from vegetative cells can be explained from the modifications in microstructure of Viscozyme L-treated coconut kernels as compared to those of the control (untreated coconut kernels). Further, they reported that the regular arrangement of cells enclosed within the cell wall can be seen in the untreated cell wall; whereas the microstructure of Viscozyme L-treated coconut kernels was observed with the collapse of cell wall structure due to the breakdown of the complex arrangement of polysaccharides in cell walls (Ravindra and John, 2013). These observations are in corroboration with our findings from the present study (Figure 9). In Figure 9, there was a clear indication of damage to cell walls after enzymatic pretreatment; whereas comparatively it was not that effective in the soxhlet extraction. Drastic changes in seed morphology can be seen before and after treatment (Figure 9), for example, among the untreated whole seed and enzyme-treated whole seed (see pics of top left 1 and 2), as well as in seed coat and cotyledon (see pics of 1 and 2 from left). As can be seen in Figure 9, remarkable cotyledon cell disruption was evident in the kernels treated with Viscozyme as it debilitated the oil-bearing seed cotyledon cell-wall, facilitating oil release during the oil extraction process. The enhanced oil efficiency achieved was due to an additional breaking of the cotyledon cells making the oil bodies effectively released and the kernels' structure more permeable, therefore allowing more efficient percolation of the hexane and consequently enhancing the liberation of the oil.

Therefore, enzymatic formulations with cellulase and hemicellulase activities are the most suitable for the purpose of destroying cell walls as cellulose and hemicelluloses are the integral part of the complex polysaccharides present in them. Enzymes need to exhibit optimal efficacy to destroy the cell wall in such a way that total oil is extracted from its layers. Optimum $\mathrm{pH}$, temperature, reaction time and enzyme concentrations collectively play a crucial role in exhibiting this ability. The present study also found that treating mustard kernels with 'Viscozyme L' broke down the cytoplasmic cells of the kernels and caused the inner cotyledon structure to loosen, which caused the removal of the pectin layer, diffusion of the granules and expansion of the cotyledon cells. 

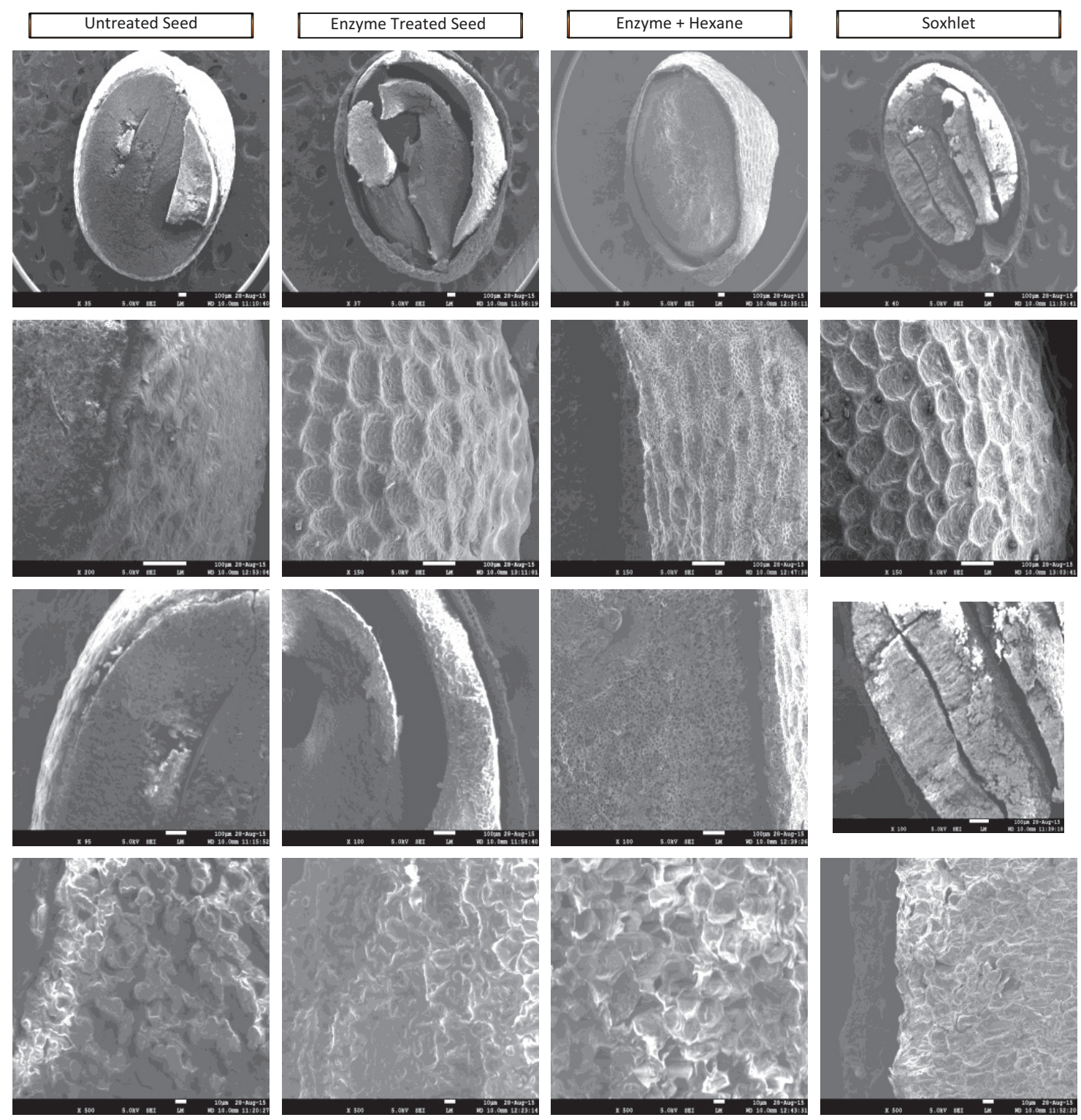

FIGURE 9. Effect of enzyme pre-treatment on mustard microstructure.

\section{CONCLUSIONS}

The objective of this study was to investigate the aqueous enzymatic extraction for recovery of oil from mustard seeds by optimizing the process conditions such as reaction time, enzyme dosage, amount of buffer solution, temperature and $\mathrm{pH}$ for extracting the maximum amount of oil using Viscozyme $\mathrm{L}$ as a catalyst. The degree of hydrolysis of mustard oilseeds was significantly affected by the hydrolysis conditions, including reaction time, enzyme dosage, amount of buffer solution, temperature and $\mathrm{pH}$. Under optimal conditions a maximum extractability of $38.761 \%$ was obtained. In addition, the optimization of the process was carried out through statistical analysis using surface response methodology. The above study gives a complete idea of the enzymatic pre-treatment of mustard seeds using Viscozyme L, the effect of enzyme on seed coat and the use of the surface response methodology to assess the determinant factors in the central composite design. The enzymatic pre-treatment makes the inner structures less tightly bound and compact, thus enabling easier removal of oil from the cells which leads to a higher oil recovery than the control. Incubation temperature, $\mathrm{pH}$, reaction time, and enzyme concentration affect the percentage of oil recovery and these values should be in the range of maximum activity of the enzyme, so that the quality of the product is not affected. 


\section{ACKNOWLEDGMENTS}

This work was carried out with the financial grant provided by Council of Scientific and Industrial Research, Govt. of India under the project PEOPLE HOPE (CSC-0112).

\section{REFERENCES}

Abdulkarim SM, Lai OM, Muhammad SKS, Long K, Ghazali HM. 2006. Use of enzymes to enhance oil recovery during aqueous extraction of Moringa oleifera seed oil. J. Food Lipids 13, 113-130. https://doi.org/10.1111/j.1745-4522. 2006.00038.x

Abul FMM, Badry NE, Ammar MS. 2011. Nutritional and chemical evaluation for two different varieties of mustard seeds. World Appl. Sci. J. 15, 1225-1233.

Dandjouma AKA, Tchiegang C, Kapseu C, Linder M, Parmentier M. 2008. Enzyme-assisted hexane extraction of Ricinodendron heudelotii (Bail.) Pierre ex Pax seeds oil. Int. J. Food Sci. Technol. 43, 1169-1175. https://doi. org/10.1111/j.1365-2621.2007.01583.x

Danso BE. 2011. Effect of enzyme and heat pretreatment on sunflower oil recovery using aqueous and hexane extractions.Int. J. Chem. Biomol. Eng. 4, 28-34.

Dobozi MS, Halfisz A, Kozma K, Szakacs G. 1988. Enhancement of mustard oil yield by cellulolytic pretreatment. App. Microbiol. Biotechnol. 29, 39-43. https://doi.org/10.1007/ BF00258348

Domínguez H, Nunez MJ, Lema JM. 1994. Enzymatic pretreatment to enhance oil extraction from fruits and oilseeds: A review. Food Chem. 49, 271-286. https://doi. org/10.1016/0308-8146(94)90172-4

Fahad MAJ, Mohammed SAJ. 2012. Chemical composition and fatty acid content of some spices and herbs under Saudi Arabia conditions. The Sci. World J. (Article ID: 859892). https://doi.org/10.1100/2012/859892

Harinder SO, Neha B, Sandeep SD, Simranjeet K, Praveen VV, Vinod KB, Ramabhau TP 2012. Enhanced oil recovery by pretreatment of mustard seeds using crude enzyme extract obtained from mixed-culture solid-state fermentation of kinnow (Citrus reticulata) waste and wheat bran. Food Bioprocess Technol. 5, 759-767. https://doi.org/10.1007/ s11947-010-0380-y

Koehler J, Marschner V, Winter B. 2008. Improved procedure for the extraction of oil from seeds. PCT Int. Appl. WO 2008080495 A1 20080710
Olsen BS. 1986. Enzyme process for extraction of rape seed oil. Process Development Bulletin No.2. Novo F-865268/HSO.

Pawanpreet S, Singh AK. 2013. Optimization of operational parameters for enhancement of oil recovery from mustard seeds using mechanical expression. Int. J. Sci. Eng. Res. 4, 583-589.

Ravindra KA, John DBS. 2014. Optimization of viscozyme-L assisted extraction of coconut milk and virgin coconut oil. Asian J. Dairy Food Res. 33, 276-284. https://doi.org/ 10.5958/0976-0563.2014.00617.4

Sarkar BC, Pandey S, Kumbhar BK, Agrawal YC. 2004. Aqueous oil extraction from enzyme pretreated sesame seed and process parameters optimization. J. Food Sci. Technol. 41, 604-608.

Sengupta R, Bhattacharyya DK. 1996. Enzymatic extraction of mustard seed and rice bran. J. Am. Oil Chem. Soc. 73, 687-692. https://doi.org/10.1007/BF02517941

Shabtai Y, Gotshal N, Ramot O, Wisniak J. 1998. Enzymatic pretreatment of jojoba seeds to facilitate oil extraction. Ind. J. Chem. Technol. 5, 124-130.

Shah S, Sharma A, Gupta MN. 2004. Extraction of oil from Jatropha curcas L. seed kernels by combination of ultrasonication and aqueous enzymatic oil extraction. Biores. Technol. 96, 121-123. https://doi.org/10.1016/j.biortech. 2004.02.026

Singh P, Singh AK. 2013. Optimization of operational parameters for enhancement of oil recovery from mustard seeds using mechanical expression. Int. J. Sci. Eng. Res. 4, 583-589.

Solmaz T, Levente LD. 2013. Aqueous and enzymatic extraction processes for the production of food grade proteins and industrial oil from dehulled yellow mustard flour. Food Res. Int. 52, 547-556. https://doi.org/10.1016/j.foodres. 2013.03.005

Stamenković OS,Ivica GD, Milan DK, Petar MM, Vlada BV. 2018. Optimization and kinetic modeling of oil extraction from white mustard (Sinapis alba L.) seeds. Ind. Crops and Prod. 121, 132-141. https://doi.org/10.1016/j. indcrop.2018.05.001

Swati, Sneha S, Madhusweta D. 2015. A brief overview: Present status on utilization of mustard oil and cake. Ind. J. Trad. Knowl. 14, 244-250.

Wang JG, Zhang H, Liu F, Liu DY, Pan MZ, Yu DY. 2014. Optimization of enzymatic pretreatment process for pressing of evening primrose oil. Shipin Kexue 35, 96-101.

Zu T, He M, Zhang L. 2013. Study on aqueous enzymatic extraction of oil from rubber seeds. Zhongguo Liangyou Xuebao 28, 37-42. 